\title{
Brief ex vivo Fas-ligand incubation attenuates GvHD without compromising stem cell graft performance
}

\author{
Hilit Levy-Barazany ${ }^{1} \cdot$ Liat Shachnai-Pinkas $^{1} \cdot$ Galina Rodionov $^{1} \cdot$ Alex Saar $^{1} \cdot$ Michal Rosenzwaig $^{1} \cdot$ Liron Gez $^{1}$ • \\ Anastasia Rodin ${ }^{1} \cdot$ Nitzan Marelly ${ }^{1}$ - Michal Abraham ${ }^{2} \cdot$ Inbal Mishalian $^{2} \cdot$ Hila Wildbaum $^{3} \cdot$ Tamar Katz $^{3}$. \\ Yuval Baar ${ }^{4} \cdot$ Shai Yarkoni $^{1} \cdot$ Ronit Bakimer-Kleiner ${ }^{1} \cdot$ Amnon Peled $^{2} \cdot{\text { Tsila Zuckerman } \mathbb{D}^{3} \cdot \text { Jerry Stein }}^{4,5}$
}

Received: 29 October 2019 / Revised: 22 April 2020 / Accepted: 1 May 2020 / Published online: 20 May 2020

(c) The Author(s) 2020. This article is published with open access

\begin{abstract}
Graft versus host disease (GvHD) remains a limiting factor for successful hematopoietic stem cell transplantation (HSCT). $\mathrm{T}$ cells and antigen-presenting cells (APCs) are major components of the hematopoietic G-CSF mobilized peripheral blood cell (MPBC) graft. Here we show that a short incubation $(2 \mathrm{~h}$ ) of MPBCs with hexameric Fas ligand (FasL) selectively induces apoptosis of specific donor $\mathrm{T}$ cell subsets and APCs but not of $\mathrm{CD} 34^{+}$cells. FasL treatment preferentially induces apoptosis in mature $\mathrm{T}$ cell subsets which express high levels of Fas (CD95), such as $\mathrm{T}$ stem cell memory, $\mathrm{T}$ central memory, and $\mathrm{T}$ effector memory cells, as well as $\mathrm{T}_{\mathrm{H}} 1$ and $\mathrm{T}_{\mathrm{H}} 17$ cells. Anti-CD3/CD28 stimulated $\mathrm{T}$ cells derived from FasL-treatedMPBCs express lower levels of CD25 and secrete lower levels of IFN- $\gamma$ as compared to control cells not treated with FasL. FasL treatment also induces apoptosis of transitional, naïve, memory and plasmablastoid B cells leading to a reduction in their numbers in the graft and following engraftment in transplanted mice. Most importantly, ex vivo treatment of MPBCs with FasL prior to transplant in conditioned NOD-scid IL2R $\gamma^{\text {null }}$ (NSG) mice prevented GvHD while preserving graft versus leukemia $(\mathrm{GvL})$ effects, and leading to robust stem cell engraftment.
\end{abstract}

\section{Introduction}

Allogeneic hematopoietic stem-cell transplantation (HSCT) can cure a wide range of malignant and non-malignant hematological diseases. Following transplantation of G-

These authors contributed equally: Hilit Levy-Barazany, Liat Shachnai-Pinkas, Tsila Zuckerman, Jerry Stein

Supplementary information The online version of this article (https:// doi.org/10.1038/s41409-020-0941-2) contains supplementary material, which is available to authorized users.

Shai Yarkoni

shai@cellect.co

1 Cellect Biotherapeutics Ltd., Kfar-Saba, Israel

2 Goldyne Savad Institute of Gene Therapy, Hebrew University of Jerusalem, Jerusalem, Israel

3 Hematology Department and Bone Marrow Transplantation Unit, Rambam Health Care Campus, Haifa, Israel

4 BMT Unit, Department of Pediatric Hematology Oncology, Schneider Children's Medical Center, Petach Tikva, Israel

5 Sackler Faculty of Medicine, Tel Aviv University, Tel Aviv, Israel
CSF-mobilized peripheral blood cells (MPBCs) [1], T cells that are contained in the graft promote hematopoietic engraftment, T-cell immunity and potent graft versus leukemia/lymphoma effects (GvL) [2-4]. A double-edged sword, these $\mathrm{T}$ cell can also mediate graft-versus-host disease (GvHD) when they recognize and respond to host allo-antigens presented by host or donor antigen-presenting cells (APCs) [5, 6].

A variety of in vivo or ex vivo modalities are available to prevent GvHD, but these same agents and procedures may attenuate immune reconstitution, increase the risk of infections and/or abrogate T-cell-mediated GvL effects $[7,8]$.

It has been shown in both preclinical and clinical models that specific $\mathrm{T}$ cell subsets exert positive and negative control over the GvHD reaction. In mice, infusion of naïve $\mathrm{T}$ cells $\left(\mathrm{CD}^{4} 5 \mathrm{RA}^{+}\right)$induces severe acute GvHD (aGvHD). By contrast, infusion of allogeneic $\mathrm{T}$ central memory (CM) induces milder GvHD, and T effector memory cell infusion (EM) does not cause significant GvHD [9-15]. Surprisingly, however, in a single-arm clinical trial in which CD45RA ${ }^{+}$ cells were depleted from allografts, the incidence of aGvHD was not reduced $[16,17]$. 
Fas and its cognate ligand are important regulators of diverse cellular responses. Binding of Fas ligand (FasL; CD178) to Fas (receptor; CD95) initiates a cascade of events culminating in apoptosis [18]. Under physiological conditions, this process curbs exuberant immune responses [19-21]. In the transplant setting, soluble FasL efficiently induces apoptosis in donor anti-host $\mathrm{T}$ cells that have been primed by co-culture with irradiated host cells (the mixed lymphocyte reactions (MLR)). Infusion of MLR-primed lymphocytes followed by ex vivo FasL treatment prevents GvHD in preclinical models while preserving antitumor reactivity [22]. Similar results were obtained by ex vivo FasL/MLR depletion of allo-reacting human donor anti-host $\mathrm{T}$ cells [23]. Askenasy et al. demonstrated that ex vivo incubation of recipient- naïve donor mouse lymphocytes with FasL causes apoptosis of activated CD8 and CD4 cells with a concurrent increase in the regulatory $\mathrm{T}$-cell (Treg) population [24]. Importantly, these authors showed that treatment of murine recipient-naïve haploidentical splenocytes with FasL in the context of F1 to hybrid transplantation led to lower clinical and histological GvHD scores of skin and gastrointestinal tract as compared with the fatal GvHD seen following the infusion of control splenocytes. Surprisingly, incubation of allografts with FasL (a protein usually associated with apoptosis and cell death) actually facilitated hematopoietic progenitor engraftment and showed trophic effects on primitive hematopoietic precursors. Mice so engrafted demonstrated preserved and potent graft-versustumor reactions [24].

As a prelude to the clinical use of FasL to prevent GvHD in patients undergoing stem cell transplantation, we have explored the effects of a brief $(2 \mathrm{~h})$ incubation of MPBCs derived from healthy, adult donors with FasL on graft composition ( $\mathrm{T}$ cell subsets, antigen-presenting cells, in vitro hematopoietic colony formation and $\mathrm{CD}_{3} 4^{+}$hematopoietic progenitor cells). FasL-treated MPBC's were infused in immune-deficient mice (both tumor- and non-tumor-bearing) to assess the impact of FasL exposure on the development of both GvHD and GvL. We demonstrate that ex vivo treatment of MPBCs with FasL prior to infusion in NSG mice prevented GvHD in this xenograft setting while preserving both robust stem cell engraftment and GvL.

\section{Materials and methods}

\section{Apheresis sample collection and FasL treatment}

G-CSF mobilized peripheral blood cells (MPBCs) were collected by apheresis from healthy donors at the Schneider Children Medical Center, (Institutional Review Board [IRB] approval No. 0613-14-RMC) or at Rambam Medical Center, (IRB approval No. 506-14-RMB).
Ex vivo incubation of MPBCs with Fas ligand, was performed in a closed infusion bag. In brief, MPBC's were washed and re-suspended in incubation medium (SCGM, CellGenix, Portsmouth, NH, USA) to which $100 \mathrm{ng} / \mathrm{ml}$ of hexameric FasL (MegaFasL, AG-40B-0130-C010, Adipogen, San Diego, CA, USA) was added. After $2 \mathrm{~h}$ at $37^{\circ} \mathrm{C}$ in $5 \% \mathrm{CO}_{2}$, cells were washed and re-suspended in transplantation buffer composed of PlasmaLyte A (FKE0324, Baxter Healthcare, Norfolk, UK) and 5\% Human Albumin Solution (Zenalb20, Bio Products Laboratory Limited, Hertfordshire, UK). Untreated control MPBCs were stored at $2-8{ }^{\circ} \mathrm{C}$ until use.

\section{Colony-forming unit assay}

In vitro colony-forming assays were used as surrogate measures of graft potency. Mononuclear fraction was separated over lymphocyte separation medium (LSM, MP Biomedicals, Santa Ana, California, US). Cells were diluted with IMDM $+2 \%$ FBS and MethoCult ${ }^{\mathrm{TM}} \mathrm{H} 4034$ medium, seeded in a 6 well SmartDish plate (all reagents purchased from StemCell Technologies, Vancouver, BC, Canada) and incubated at $37{ }^{\circ} \mathrm{C}$, in $5 \% \mathrm{CO}_{2}$, with $\geq 95 \%$ humidity for 12-16 days. The number of colonies was expressed per $1 \times$ $10^{4}$ seeded total nucleated cells (TNCs).

For detection of human colony-forming cells from mouse bone marrow $(\mathrm{BM})$, single-cell suspensions of mouse BM were lysed using ACK Lysis buffer (A10492-01, Thermo Fisher Scientific, Waltham MA, USA) and diluted with $\mathrm{IMDM}+2 \% \quad$ FBS and MethoCult ${ }^{\mathrm{TM}} \mathrm{H} 4534$ medium (StemCell technologies, Vancouver, BC, Canada).

\section{Flow cytometry}

Red blood cells from MPBCs or mouse spleen, blood or BM cell suspensions were lysed using ACK lysis buffer (A1049201, Thermo Fisher Scientific, Waltham MA, USA) and $1 \times$ $10^{6}$ cells were stained with various combinations of fluorescence- conjugated anti-human antibodies (accept for CD45 that was of either mouse or human origin as indicated in the text). For cell surface staining, cells were incubated with antibodies for $15 \mathrm{~min}$ at $4{ }^{\circ} \mathrm{C}$ in the dark. Intracellular staining was performed using either Inside Stain Kit or FoxP3 Staining Buffer Set (130-090-477 or 130-093-142, respectively, Miltenyi Biotech, Bergisch Gladbach, Germany) according to manufacturer's instructions.

The following antibodies were used: anti- mouse CD45 (130-102-412), human CD45 (130-098-143, 130-098-151, 130-098-141, 130-098-148, 130-104-566, 130-110-637), CD34 (130-081-002, 130-090-954), CD90 (130-099-289), CD3 (130-109-460, 130-109-466), CD4 (130-110-680), CD8 (130-109-454), CCR7 (130-108-309), CD45RA (130-108-784, 130-110-637), LFA1 (130-105-437), CD95 
(130-104-232), CXCR3 (130-101-378), CCR6 (130-100377), CD25 (130-109-021), CD33 (130-111-021), CD19 (130-113-642, 130-110-249), CD27 (130-099-499), CD38 (130-108-862), HLA-DR (130-104-825), IL17 (130-100077), IFN- $\gamma$ (130-097-944) and FoxP3 (130-098-119) all purchased from Miltenyi Biotech (Bergisch Gladbach, Germany); matched isotype controls were used as negative control.

Induction of early apoptosis was evaluated using Annexin $\mathrm{V}$ and 7-Aminoactinomycin D (7-AAD) (BMS500FI and 00-6993 respectively, Invitrogen, Thermo Fisher Scientific, Waltham MA, USA) staining. Early apoptosis was calculated as $\%$ Annexin $^{+} / 7-\mathrm{AAD}^{-}$cells of indicated populations.

Data was acquired using MACSQuant analyzer 10 and analyzed using MACSQuant software 2.11 (Miltenyi Biotech, Bergisch Gladbach, Germany). Analysis of CD34 ${ }^{+}$ cells was conducted according to the ISHAGE guidelines $[25,26]$.

\section{Purification of $\mathrm{CD}_{3} 4^{+}$or $\mathrm{CD}^{+} \mathrm{T}$ cells and $\mathrm{T}$ cell activation}

$\mathrm{CD} 4^{+}$cells were selected from either FasL treated or control MPBCs using CD34 cell-separation microbeads (130-046703, Miltenyi Biotech, Bergisch Gladbach, Germany). T cell isolation was performed by immunomagnetic negative selection (EasySep, StemCell technologies, Vancouver, BC, Canada). T cells isolated from MPBCs and FasL-treatedMPBCs were stimulated using Human T-Activator CD3/ CD28 (111.31D, Dynabeads, Invitrogen, Carlsbad, CA, USA) at a 1:10 bead:cells-ratio. IFN- $\gamma$ secretion was detected by ELISA assay (Quantikine, R\&D systems, Minneapolis, MN, USA) and cells were subjected to flow cytometry assay.

\section{Xenogeneic GvHD and engraftment models}

NOD-scid IL2Rgamma-null (NSG) mice (Jackson Laboratory, Bar Harbor MN, USA) were housed in a pathogen-free facility and handled in accordance with the guidelines of the Animal Care and Use Committee of the Rabin Medical Center, Petach Tikva, Israel. For each experiment 7-10 (acceptable group size based on statistical and ethical considerations) female NSG mice (7-9 weeks) were irradiated with 2 or 2.75 Gy (CLINACDBX linear accelerators, Varian Medical System, Palo Alto, CA, USA) $24-48 \mathrm{~h}$ prior to infusion of $\sim 5 \times 10^{6}$ unfractionated MPBCs (total nucleated cell (TNC)) or $0.1 \times 10^{6}$ purified $\mathrm{CD} 34^{+}$cells/mouse, respectively. Mice were randomized according to age and body weight. Monitoring of GvHD clinical score was carried out twice weekly according to the murine clinical grading system described by Cooke et al. [27]. Weight loss, hunched posture, skin lesions, dull fur, and mobility were each assigned scores of 0 (absent), 1 (moderate) or 2 (severe). The investigator was blinded to the group allocation during each experiment.

Mice were sacrificed in case of weight loss $\geq 20 \%$ of initial weight or upon reaching a clinical GvHD score of $\geq 7$. At each study termination endpoint; spleen, blood and BM were harvested, and human cell engraftment was analyzed by flow cytometry. Mice that exhibited $<1 \%$ hCD45 in their bone marrow or spleen and $<0.1 \%$ hCD45 in their blood were considered as not engrafted and were excluded from mean calculation.

During the respective scheduled study termination, spleen weight was recorded. The liver of each animal was collected and fixed for at least $48 \mathrm{~h}$ in $10 \%$ natural buffered formalin (approximately 4\% paraformaldehyde) and H\&E staining of Paraffin sections was performed. Histopathological changes were scored using semi-quantitative grading (0-4): $0=$ No Lesion, $1=$ Minimal Change, $2=$ Mild Change, $3=$ Moderate Change, $4=$ Marked Change.

\section{In vivo GvHD versus leukemia models}

Mice were housed in a pathogen-free facility and handled in accordance with the guidelines of the Animal Care and Use Committee of the Hadassah Medical Center, Jerusalem, Israel. Mice were irradiated with $2 \mathrm{~Gy}$, and MV4$11\left(10 \times 10^{6}\right.$ cells/mouse, ATCC CRL-9591, Manassas, VA, USA were infused intravenously (IV) within $24 \mathrm{~h}$. After 4-6 h, mice were infused IV with either FasL-treatedMPBCs, control MPBCs or vehicle. Monitoring of GvHD clinical score was carried out twice weekly until 3 weeks post-transplantation, when the mice were sacrificed; blood, $\mathrm{BM}$ and spleens were harvested. The leukemic burden and the degree of human leukocyte engraftment were assessed using flow cytometry (MACSQuant Analyzer 10 and MACSQuantify Software 2.11, Miltenyi Biotech, Bergisch Gladbach, Germany). The percentage and relative number of the leukemic cells ( $\mathrm{hCD} 45^{+} \mathrm{hCD} 123^{+}$), human hematopoietic cells $\left(\mathrm{hCD} 45^{+} \mathrm{hCD} 123^{-}\right.$) and murine hematopoietic cells $\left(\mathrm{mCD} 45^{+} \mathrm{hCD} 45^{-} \mathrm{hCD} 123^{-}\right.$) were evaluated (all antibodies manufactured by Miltenyi Biotech, Bergisch Gladbach, Germany).

\section{Migration assay and integrin expression}

MPBCs control and FasL-treated-MPBCs $\left(2 \times 10^{5}\right.$ TNCs $)$ were placed in the upper compartments of transwell plates (CA-342, Corning, Corning, NY, USA) and their migration in response to $100 \mathrm{ng} / \mathrm{ml}$ human CXCL12/stromal derived factor-1 (SDF1) (350-NS-010, R\&D Systems) was tested. Chemokine receptor and integrin expression were assessed using anti-CXCR4, anti-LFA1, and anti-VLA4 antibodies (Miltenyi Biotech, Bergisch Gladbach, Germany). 


\section{Statistical analysis}

For every figure, statistical tests are indicated.

ANOVA parametric test or two tailed paired T-test for comparison MPBC vs MPBC + FasL samples, data presented as average of three technical replicates for each of at least three independent experiments each performed using individual MPBC donation.

Mann-Whitney test and Log-rank (Mantel-Cox) test for animal studies, at least seven animals/ group was tested.

Two tailed unpaired Student's $t$ test was applied for technical triplicates of individual representative tests. GraphPad Prism version 8.0 (San Diego, CA USA) was used for statistical analyses and figure generation.

\section{Results}

\section{Brief incubation of G-CSF MPBCs with Fas ligand results in selective reduction of $\mathrm{CD}^{+} \mathrm{T}$ cells while maintaining $\mathrm{CD}_{3} 4^{+}$viability and functionality}

MPBCs from 25 healthy donors were separately incubated for $2 \mathrm{~h}$ with hexameric FasL or with control media. Early apoptosis signal and reduction in the percentage of $\mathrm{CD}^{+} \mathrm{T}$ cells were detected in the FasL-treated samples, while $\mathrm{CD} 34^{+}$percentage and viability were unaffected (Fig. 1a-d). FasL incubation did not affect the percentage of immature $\mathrm{CD} 34^{+} \mathrm{CD} 38^{\text {low }}$ stem cells, multipotent $\mathrm{CD} 45 \mathrm{RA}^{-}$ $\mathrm{CD}^{-} 0^{-}$stem cells, or self-renewing $\mathrm{CD}_{45 \mathrm{RA}^{-} \mathrm{CD} 90^{+}}$ hematopoietic stem cells [28] (Fig. 1e-g). Furthermore, FasL treatment did not reduce the number of erythroid and myeloid colony-forming units that formed in semi-solid, growth factor-supplemented media (Fig. 1h). These results suggest a selective effect of the FasL-treatment on $\mathrm{CD}^{+} \mathrm{T}$ cells, with preservation of $\mathrm{CD} 34^{+}$progenitor cell viability and clonogenic potential.

Engraftment of HSPCs is dependent on their ability to home to and be retained in marrow niches [29]. The chemokine CXCL12/SDF1 is responsible for the early phases of HSPCs homing and retention in these niches via binding of its cognate receptor, CXCR4. CXCR4-dependent homing and retention of HSPCs also requires integrins such as VLA-4 and LFA-1 [30]. Ex vivo FasL incubation for $2 \mathrm{~h}$ did not effect the expression of CXCR4, or of integrins LFA-1 or of VLA-4 on CD34 ${ }^{+}$HSPCs. In functional migration assays, $\mathrm{CD} 34^{+}$HSPCs migration towards a CXCL12/SDF1 gradient was not effected by ex vivo FasL treatment (Supplementary Fig. 1a, b).

Engraftment rates of xenotransplanted human leukocytes and hematopoietic progenitor cells (percentage of human $\mathrm{CD} 45^{+}$and $\mathrm{CD} 34^{+} \mathrm{CD} 38^{\text {low }}$ cells, respectfully) derived from either control or FasL-treated- MPBC grafts were similar in marrow aspirates from NSG mice 4 weeks after transplantation (Fig. 1i, j). Furthermore, similar percentage of mature human $\mathrm{CD} 19^{+} \mathrm{B}$ cells, $\mathrm{CD} 33^{+}$and $\mathrm{CD} 14^{+} \mathrm{CD} 16^{-}$myelo-monocytic, as well as $\mathrm{CD} 56^{+} \mathrm{CD} 16^{-}$ NK cells were observed following control- or FasLtreatment of xenografts (Fig. 1k). A small but statistically significant increase in the number of human $\mathrm{CFU}$ was observed in the $\mathrm{BM}$ of mice transplanted with $\mathrm{CD} 34^{+}$cells derived from FasL-treated-MPBCs compared to the control treatment group at 4 weeks (Fig. 11). These results demonstrate that ex vivo FasL treatment does not impair short-term engraftment and differentiation of FasL-treatedMPBCs.

\section{Fas ligand induces apoptosis in specific $\mathbf{T}$ cell subsets, reduces expression of activation proteins, and attenuates IFN- $\gamma$ secretion}

GvHD is initiated by alloreactivity generated within specific donor-derived $\mathrm{T}$ cell subsets; we examined the differential apoptosis-inducing effects of brief ex vivo FasL incubation on $\mathrm{T}$ cell subsets present in MPBC grafts. Rates of FasLinduced, early apoptosis were highest among naïve $\mathrm{T}$ stem cell memory $\left(\mathrm{T}_{\mathrm{SCM}}\right)$, mature helper $\left(\mathrm{T}_{\mathrm{H}}, \mathrm{CD}^{+}\right)$and cytotoxic $\left(\mathrm{T}_{\mathrm{C}}, \mathrm{CD}^{+}{ }^{+}\right) \mathrm{T}$ cell populations (Fig. 2a, b). Differential FasL sensitivity of each $\mathrm{T}$ cell sub-population correlated with the intensity of expression of Fas receptor (CD95) on the cells of each specific population (Fig. 2c).

To simulate the allo-activation that occurs following infusion of a stem cell graft, $\mathrm{CD}^{+}$cells derived from MPBC or FasL-treated MPBC were exposed to human T-activator $\mathrm{CD} 3 / \mathrm{CD} 28$ beads for $24-48 \mathrm{~h}$; the expression of T-cell activation markers was tested. Incubation of MPBCs with FasL before $\mathrm{T}$ cell stimulation reduced the number of $\mathrm{CD} 25^{+}$cells (Fig. 3a, b) and significantly reduced both secreted IFN- $\gamma$ as well as the percentage of cells expressing IFN- $\gamma$ (Fig. 3c, d). Brief incubation with FasL reduced the percentages of $\mathrm{T}_{\mathrm{H}} 1$, $\mathrm{CD}^{+}{ }^{+} \mathrm{CXCR}^{+}{ }^{+}$cells, $\mathrm{T}_{\mathrm{C}} 1, \mathrm{CD} 8{ }^{+} \mathrm{CXCR}^{+}$cells and $\mathrm{T}_{\mathrm{H}} 17$, $\mathrm{CD}^{+}{ }^{+} \mathrm{CCR} 6^{+}$cells (Fig. 3e-h). Interestingly, we found no difference in the percentage of either $\mathrm{CD} 4{ }^{+} \mathrm{CD} 25^{+} \mathrm{FoxP} 3^{+}$or $\mathrm{CD} 8{ }^{+} \mathrm{CD} 25^{+} \mathrm{FoxP}^{+} \mathrm{T}$ regulatory cell populations following ex vivo treatment with FasL (Fig. 3i).

\section{FasL-treated-MPBCs attenuate acute GvHD and improve survival following xenogeneic transplantation}

We studied human MPBC engraftment and the development of GvHD in $\gamma$-irradiated NSG mice transplanted with either FasL-treated or control grafts. On day 18 post transplantation, the mean clinical GvHD score of control MPBC- infused mice was $6.1 \pm 1.0$, manifest as weight loss (Fig. 4a), hunched posture, ruffled fur and reduced 
a

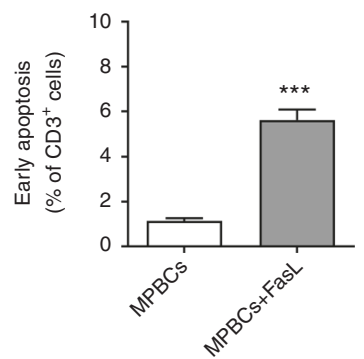

e

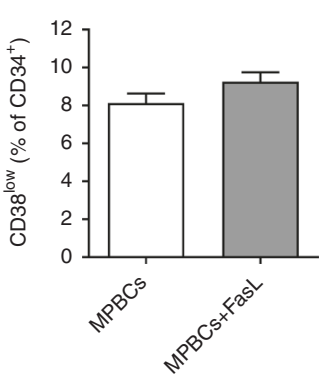

i

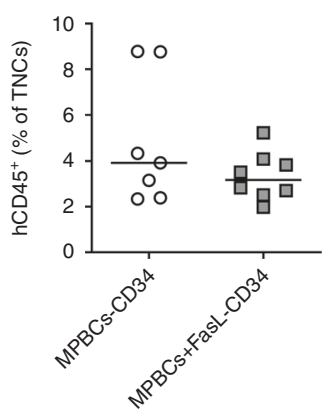

b

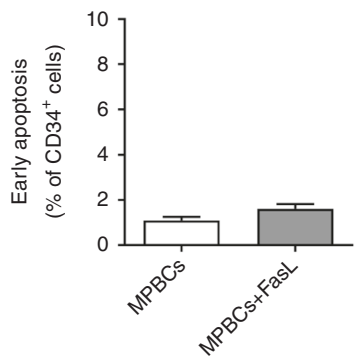

f $\underline{\underline{3}}$

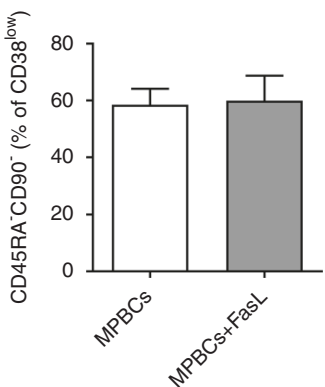

j

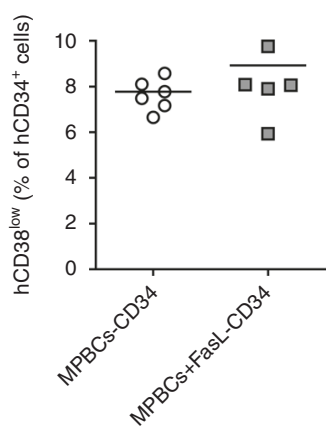

C

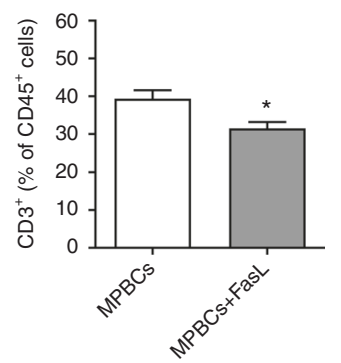

g

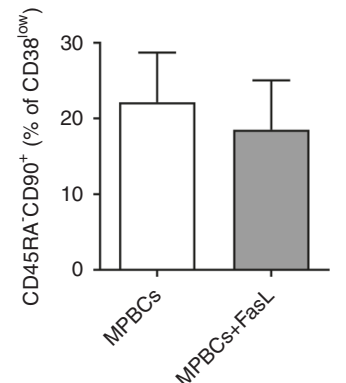

$\mathbf{K}_{\text {. }}$

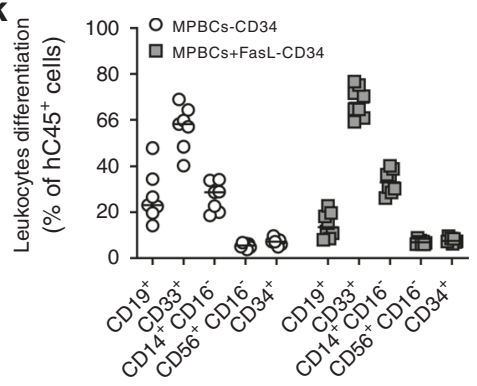

d

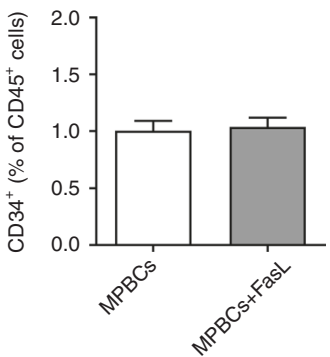

h
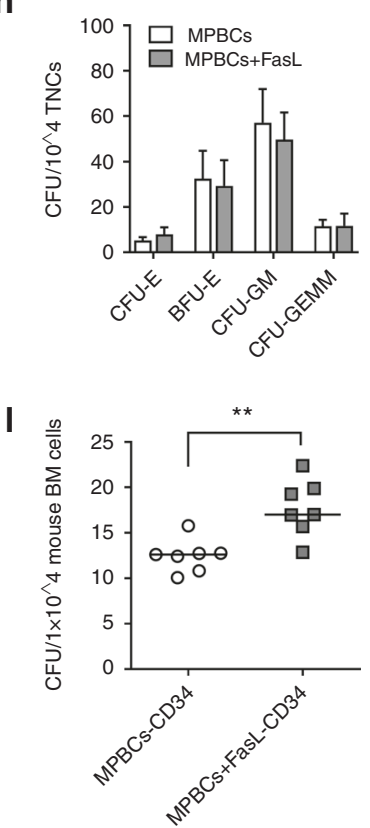

Fig. 1 FasL-treatment selectively reduces $\mathrm{CD3}^{+}$cells while $\mathrm{CDB4}^{+}$ cell number and functionality are maintained. $\mathbf{a}-\mathbf{h}$ MPBC graft characterization following FasL treatment. Percentage of annexin $\mathrm{V}$ positive a $\mathrm{CD}^{+}$and $\mathbf{b} \mathrm{CD} 34^{+}$cells. c Percentage of $\mathrm{CD}^{+}$ and $\mathbf{d ~ C D} 34^{+}$cells per total $\mathrm{CD} 45^{+}$population. HSPCs subpopulations; e Immature $\left(\mathrm{CD} 34^{+} \mathrm{CD} 38^{\text {low }}\right)$, f Multipotent progenitors $\left(\mathrm{CD} 45 \mathrm{RA}^{-} \mathrm{CD}^{-}{ }^{-}\right)$and $\mathbf{g}$ self-renewing hematopoietic stem cells $\left(\mathrm{CD} 45 \mathrm{RA}^{-} \mathrm{CD}^{+}{ }^{+}\right)$. h Colony-forming units $(\mathrm{CFU})$ profile of: erythroid progenitor cells (CFU-E and BFU-E), granulocytemacrophage progenitor cells (CFU-GM) and multipotential granulocyte, erythroid, macrophage, megakaryocyte progenitor cells (CFUGEMM). Engraftment, differentiation and CFU potential as detected in the BM of $\gamma$-irradiated $(2.75 \mathrm{~Gy})$ NSG mice, 4 weeks post

locomotion. By contrast, the mean clinical GvHD score of mice infused with FasL-treated-MPBCs was zero $(P<$ 0.001) (Fig. 4b). GvHD progressed in control-MPBC mice, and none survived to 28 days post-transplantation; by contrast, all mice transplanted with FasL-treated-MPBCs survived at the 60-day benchmark (Fig. 4c) $(P<0.0001)$.

GvHD is triggered early after transplantation when donor $\mathrm{T}$ cells home to secondary lymphoid organs, where they undergo activation and expansion before migrating into GvHD target organs [6]. We monitored splenic infiltration by human lymphocytes as a surrogate measure of in vivo

transplantation of $1 \times 10^{5}$ human $\mathrm{CD}^{+} 4^{+}$cells: $\mathbf{i}$ human leukocytes $\left(\mathrm{hCD} 45^{+}\right) \mathbf{j}$ immature $\mathrm{hCD} 34^{+} \mathrm{CD} 38^{\text {low }}$ progenitors and $\mathbf{k}$ human leukocytes subpopulations: B (hCD19+), Myelo-monocytic (hCD33 ${ }^{+}$ and $\left.\mathrm{CD} 14^{+} \mathrm{CD} 16^{-}\right)$, NK (hCD56 $\left.{ }^{+} \mathrm{CD} 16^{-}\right)$, HSPCs $\left(\mathrm{CD} 34^{+}\right)$cells and $\mathrm{I}$ number of human colony-forming cells in the mice BM. Data presented as $(\mathbf{a}-\mathbf{h})$ mean + SD or (i-l) individual mice and median. (a-d) $n=25$ or $(\mathbf{e}-\mathbf{h}) n=3$ individual MPBCs donations and (i-l) show one representative study out of two, $n=7$ (MPBC-CD34) and $n=8$ (MPBC + FasL-CD34) female mice per group transplanted with cells from one individual MPBC donation. Statistical analysis preformed using (a-d) ANOVA parametric test, $(\mathbf{e}-\mathbf{h})$ paired T-test or (i-l) Mann-Whitney test. $* P<0.05, * * P<0.01$, *** $P<0.001$.

$\mathrm{T}$ cell expansion and lymph node homing after xenotransplantation of human FasL-treated or control MPBCs in irradiated, immunodeficient mice; human hematopoietic cell engraftment in marrow and peripheral blood were monitored at the same timepoints. Spleens harvested 7 and 14 days after infusion of FasL-treated-MPBCs were significantly smaller (Supplementary Fig. 2a) and contained fewer $\mathrm{hCD}^{+} 5^{+}, \mathrm{hCD}^{+}, \mathrm{hCD} 19^{+}$, and $\mathrm{hCD}^{+} 3^{+}$cells as compared to spleens of mice infused with control MPBC grafts (Fig. 4d-g, respectively). In contrast, hematopoietic marrow engraftment, as measured by the number of human 
a

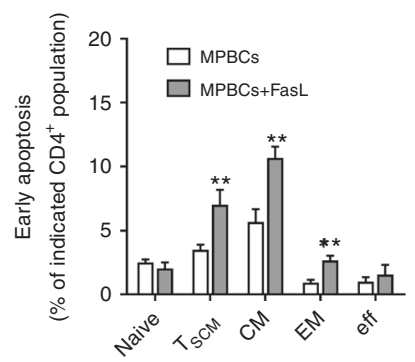

b

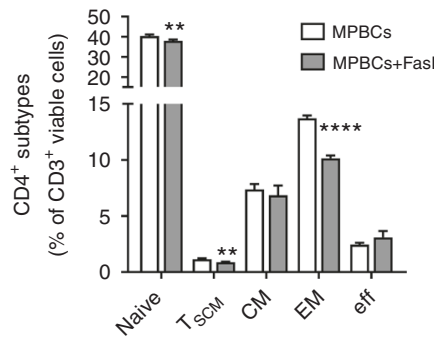

C

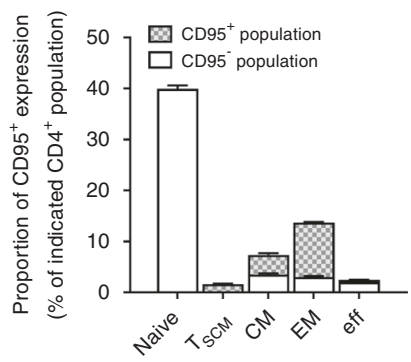

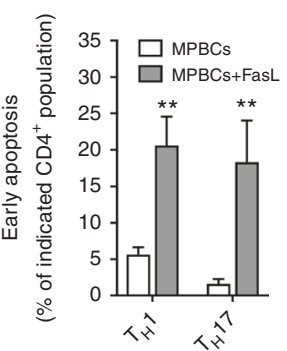
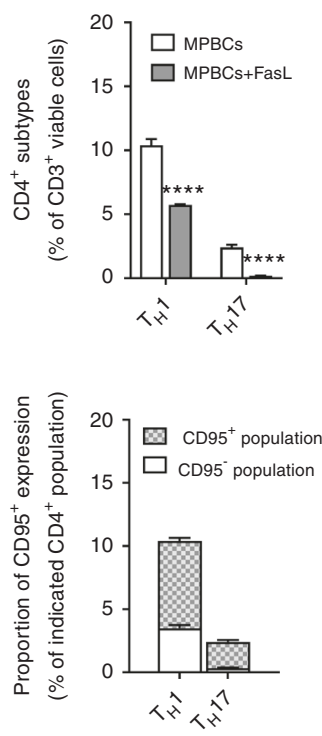

Fig. 2 Fas ligand sensitizes $\mathbf{T}$ cells to apoptosis. $\mathrm{CD} 4^{+}$and $\mathrm{CD} 8^{+} \mathrm{T}$ lymphocyte subtypes derived from FasL- treated-MPBCs and control MPBCs were analyzed using flow cytometry for (a) Percent of early apoptotic cells (Annexin $\mathrm{V}^{+}$stained cells) and (b) Percent of viable cells. The following $\mathrm{T}$ cell subtypes were analyzed: Naïve $\left(\mathrm{CCR} 7^{+}\right.$

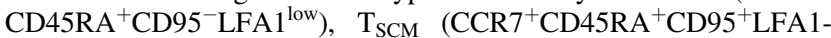
high $)$, central memory $\left(\mathrm{CM}, \mathrm{CCR} 7^{+} \mathrm{CD} 45 \mathrm{RA}^{-}\right)$, effector memory (EM,

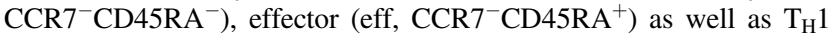

$\mathrm{CD}^{+} 4^{+}$cells (Fig. 4n) and myeloid precursors in marrow aspirates (Fig. 4k), was similar at day 14 in both control and FasL-treated-MPBC transplanted mice. Additionally, human $\mathrm{T}$ and $\mathrm{B}$ cell numbers were reduced in the marrow of recipients of FasL-treated-MPBCs as compared to control mice (Fig. $4 \mathrm{i}$ and $\mathrm{j}$ ) as where $\mathrm{hCD} 45^{+}$and $\mathrm{hCD}^{+}$cells in the peripheral blood (Fig. 41, m). Reduced clinical GvHD scores of FasL-treated grafts were paralleled by lower IFN- $\gamma$ plasma levels (Fig. 4b, o) and a reduction in histologic signs of GVHDs in the liver parenchyma of these mice (Supplementary Fig. 2b, c).

\section{Fas ligand induces apoptosis in B cell subsets}

Accumulation of $\mathrm{T}$ cells in the spleens of control MPBCs recipients suggests the presence of local antigen-presenting cells (APCs). Indeed, we noted a parallel increase in splenic
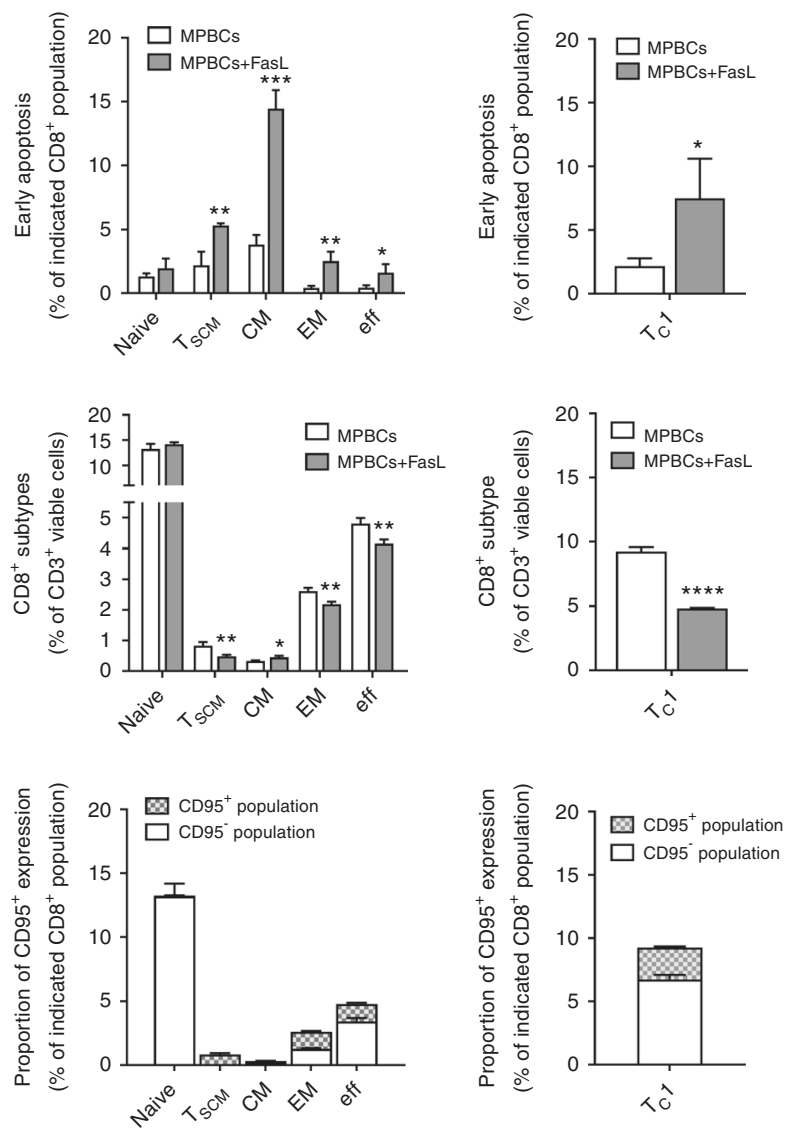

$\left(\mathrm{CD}^{+}{ }^{+} \mathrm{CXCR}^{+}\right), \mathrm{T}_{\mathrm{H}} 17\left(\mathrm{CD} 4^{+} \mathrm{CCR}^{+} \mathrm{CXCR}^{-}\right)$and $\mathrm{T}_{\mathrm{C}} 1\left(\mathrm{CD} 8^{+}\right.$ $\left.\mathrm{CXCR}^{+}\right)$. c Fas $\left(\mathrm{CD}^{+} 5^{+}\right)$expressing T-cell populations were analyzed in control MPBC. Results are presented as Mean+SD of experiments performed in triplicate. Due to high donor-dependent variability, one representative experiment out of 3 is presented. Statistical analysis was performed using unpaired, parametric Student's $t$ test $* P \leq 0.05, * * P \leq 0.01, * * * P \leq 0.001, * * * * P \leq 0.001$.

human $\mathrm{T}$ and $\mathrm{B}$ cells in our xenograft recipients following the administration of control MPBCs, and attenuation of this process in recipients of FasL-treated-MPBCs (Fig. 4f). As B cells serve as surrogate APC's in xenograft models [31, 32], B cell subsets were evaluated in FasL-treatedMPBC grafts (Fig. 5a-c). FasL treatment lead to increased apoptosis of transitional, naïve, memory and plasmablastoid $\mathrm{B}$ cells and a reduction in their relative percentage within the treated grafts (Fig. 5a, b). CD95 expression was noted in the most affected cell populations (data not shown). Ex vivo FasL treatment selectively reduced the percentage of HLA$\mathrm{DR}^{\text {high }} \mathrm{B}$ cells (Fig. 5c). Two weeks after transplantation in immune-deficient mice, transitional, naïve and plasmablastoid B cells were reduced in recipients of FasL-treatedMPBCs (Fig. 5d) as compared to recipients of control grafts. HLA-DR ${ }^{\text {high }} \mathrm{B}$ cells were selectively decreased in spleens of mice transplanted with FasL-treated-MPBCs 
a

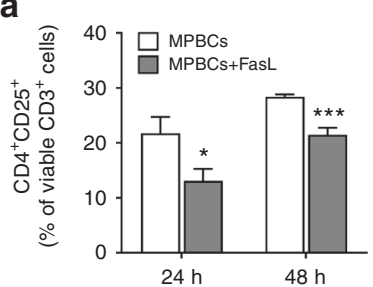

d

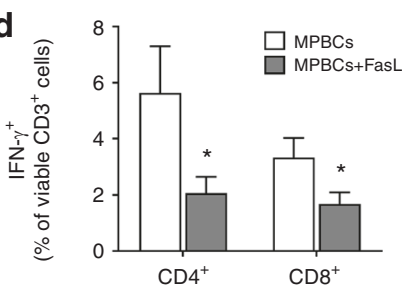

g

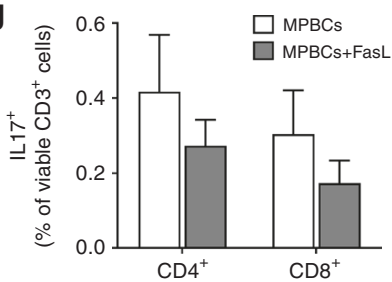

b
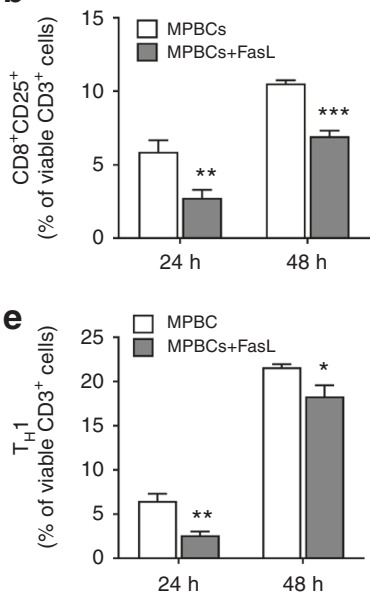

h

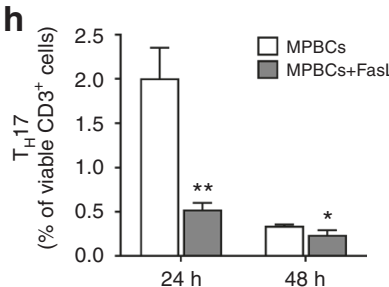

C

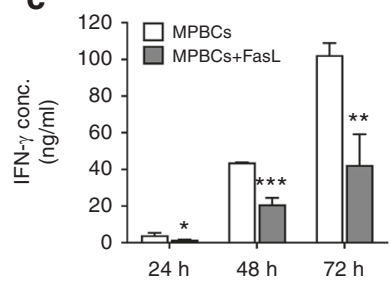

f
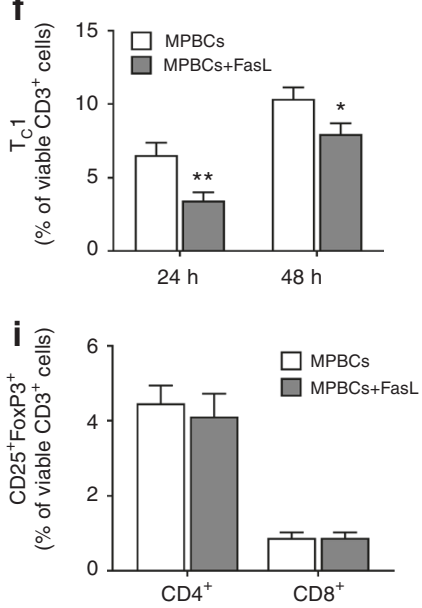

Fig. 3 Reduced activation and differentiation of FasL-treatedMPBCs derived $T$ lymphocytes in response to in vitro stimulation. T-lymphocytes isolated from FasL-treated and control MPBCs were stimulated using anti-CD3/CD28 activation beads. a Activated $\mathrm{T}$ helper $\left(\mathrm{CD} 4^{+} \mathrm{CD} 25^{+}\right)$and b $\mathrm{T}$ cytotoxic $\left(\mathrm{CD} 8^{+} \mathrm{CD} 25^{+}\right)$cells were quantified 24 and $48 \mathrm{~h}$ post stimulation using flow cytometry. c Concentration of IFN- $\gamma$ secreted to the medium of the cultured T-cells was measured 24,48 and $72 \mathrm{~h}$ post stimulation using ELISA. d The percentages of $\mathrm{CD}^{+}$and $\mathrm{CD} 8^{+}$IFN- $\gamma$ secreting $\left(\mathrm{IFN}-\gamma^{+}\right)$cells were quantified by flow cytometry $48 \mathrm{~h}$ post stimulation. e Percent of $\mathrm{TH} 1\left(\mathrm{CD}^{+} \mathrm{CXCR}^{+}\right)$and $\mathbf{f} \mathrm{TC} 1\left(\mathrm{CD}^{+} \mathrm{CXCR}^{+}\right)$cells were

as compared to mice transplanted with control MPBCs (Fig. 5e), mirroring the results of the ex vivo experiments noted above.

\section{FasL treatment maintains GvL activity while preventing GvHD}

The presence of $\mathrm{T}$ cells in the transplanted graft promotes both engraftment and GvL [33]. To study the effect of FasL treatment on GvL in vivo, we developed a novel model for concurrently testing GvHD and GvL in NSG mice. MV4-11 human leukemic cells were administered intravenously into $\gamma$-irradiated NSG mice on day $0(10 \times$ $10^{6}$ cells/mouse), and either FasL-treated or control MPBCs $\left(3 \times 10^{6}\right.$ TNCs/mouse $)$ were infused 4-6 h later. GvHD scores were recorded twice weekly for three weeks and at the timepoint at which the mice were sacrificed; leukemic burden in the marrow, spleen and blood was assessed using antibodies to human CD123 (Fig. 6a, b). As compared to mice infused with sham stem cell grafts quantified 24 and $48 \mathrm{~h}$ post stimulation using flow cytometry. $\mathrm{g}$ The percentages of $\mathrm{CD}^{+}$and $\mathrm{CD} 8^{+} \mathrm{IL} 17$ secreting (IL17 ${ }^{+}$) cells were quantified by flow cytometry $48 \mathrm{~h}$ after stimulation. h TH17 (CD4 ${ }^{+} \mathrm{CCR6}^{+}$) $\mathrm{T}$ cells populations were quantified 24 and $48 \mathrm{~h}$ post stimulation using flow cytometry. i Regulatory $\mathrm{CD}^{+}$and $\mathrm{CD} 8^{+} \mathrm{T}$ cells $\left(\mathrm{CD} 25^{+} \mathrm{FoxP}^{+}\right)$were quantified $72 \mathrm{~h}$ post stimulation using flow cytometry. Representative results of one independent study out of two is presented. Data presented as Mean $+\mathrm{SD}, n=3$. Statistical analysis was performed using unpaired, parametric t-test; $* P \leq 0.05, * * P \leq 0.01$, $* * * P \leq 0.001$.

(vehicle), leukemic burden was similarly diminished in the spleen, marrow, and blood of mice co-transplanted with either FasL-treated-MPBCs or control MPBCs $(P<$ 0.01 either transplant vs. sham) (Fig. 6c-e), suggesting that xenograft-mediated GvL was not compromised by FasL treatment. As in the previous experiments (see Fig. 4), recipients of FasL-treated-MPBCs continued to be robust, with no weight loss and with lower GvHD clinical scores as compared to mice receiving control MPBCs (Fig. 6f, g). Of note, vehicle infused mice showed worsening clinical scores due to increasing leukemic burden, and not due to GvHD (Fig. 6g). In summary, FasL permits uncoupling of GvHD and GvL effects in this xenograft model.

\section{Discussion}

In this study, we have shown that brief incubation of human stem cell grafts with FasL uncouples GvHD and GvL 


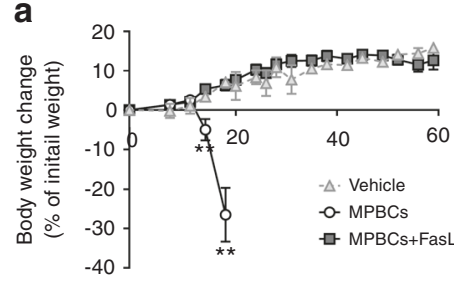

Days post transplantation b

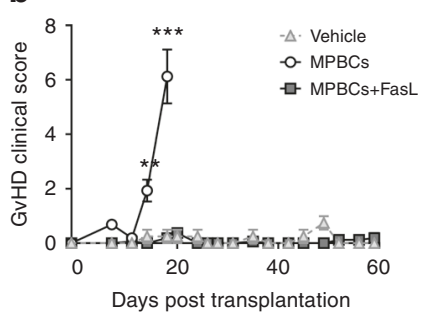

C

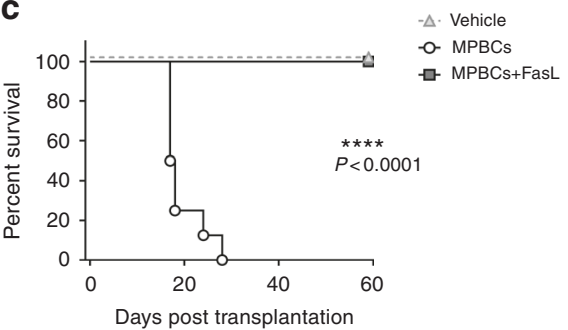

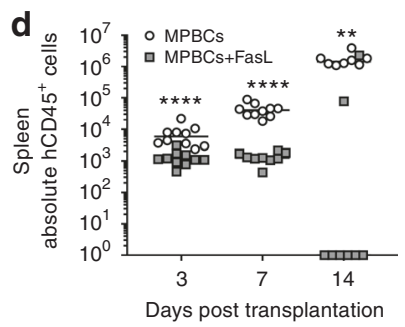

h

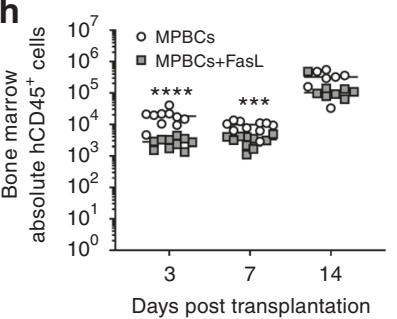

I

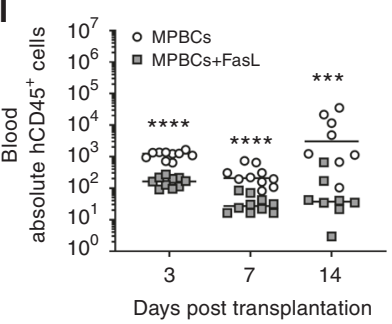

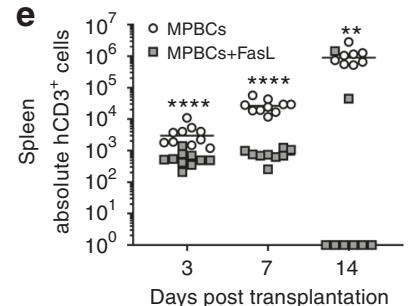
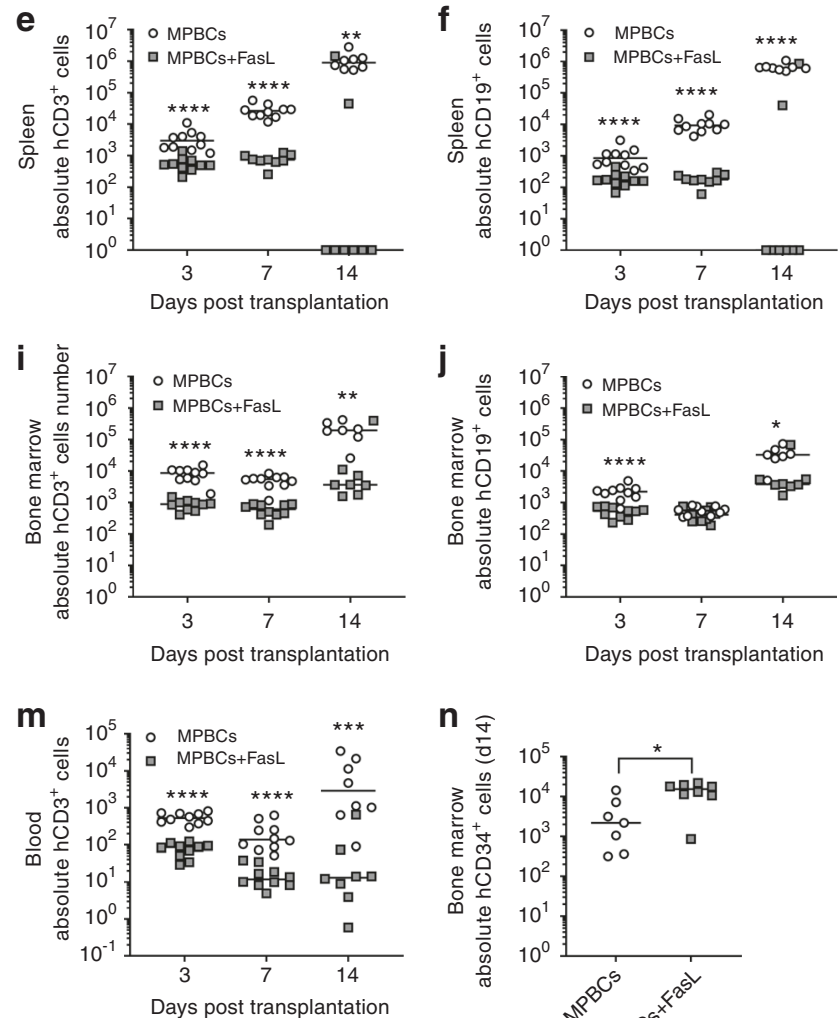

j

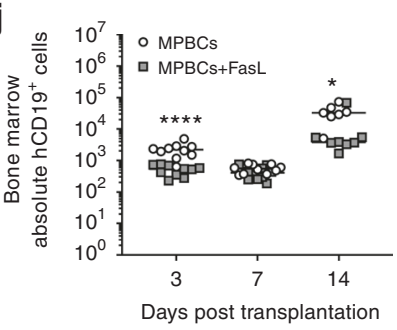

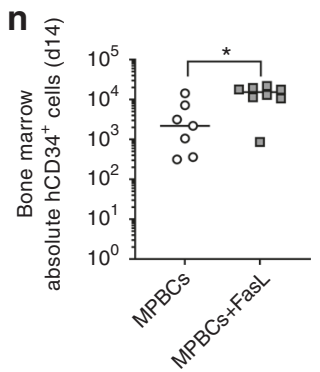
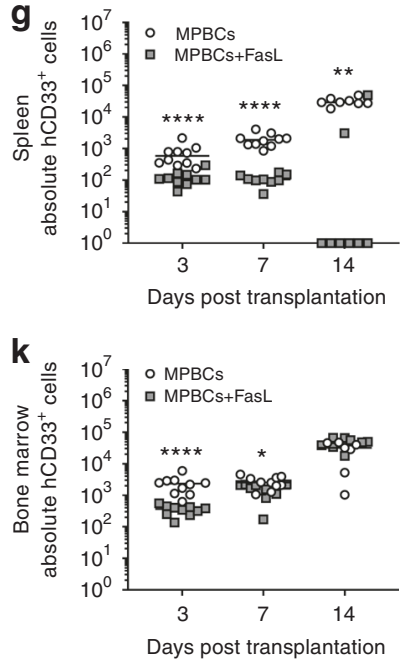

0

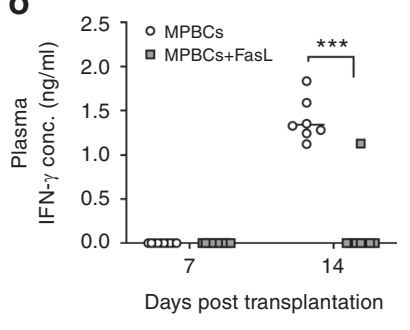

Fig. 4 FasL treatment attenuates acute GvHD in a xenogeneic GvHD model. Control MPBCs or FasL-treated-MPBCs $\left(5 \times 10^{6} \%\right.$ mouse) were transplanted into sub-lethally irradiated (2 Gy) NSG mice $(n=10$ females/group for day 3 and $7, n=8$ females/group for day $14)$; as control, vehicle (transplantation buffer) was infused $(n=2$ females/group). The mice were monitored twice a week for (a) percentage of body weight change, (b) GvHD score and (c) survival. Xenograft composition in NSG mice following transplantation of FasL-treated-MPBCs was evaluated 3-, 7- and 14-days post transplantation in the $(\mathbf{d}-\mathbf{g})$ spleen, $(\mathbf{h}-\mathbf{k}) \mathrm{BM}$ and $(\mathbf{l}-\mathbf{m})$ blood. At each indicated termination time point the absolute cell numbers of the following subtypes were measured: $\mathbf{d}, \mathbf{h}, \mathbf{I ~ h C D} 45^{+}, \mathbf{e}, \mathbf{i}, \mathbf{m ~ h C D} 3^{+}$,

effects without attenuating the engraftment potential of the cells in irradiated, immune-deficient mice. Attenuation of GvHD by brief incubation of otherwise unmanipulated human stem cell grafts with multimerized FasL occurred even in the absence of prior priming of donor $\mathrm{T}$ cells with host antigens. FasL incubation increased apoptosis of IFN- $\gamma$ producing $\mathrm{T}$ cells and of cell populations expressing high levels of $\mathrm{CD} 95$, including naïve derived $\mathrm{T}_{\mathrm{SCM}}$, mature

$\mathbf{f}, \mathbf{j}$ hCD $19^{+}$and $\mathbf{g}, \mathbf{k}$ hCD33 ${ }^{+}$(absolute cell number is the product of the percentage of each cell population and the number of cells counted by the flow cytometer after adjusting for the volume of cell suspension). $\mathbf{n}$ Absolute hCD34 ${ }^{+}$cell number in the BM. o Plasma levels of IFN- $\gamma$. a, b Data presented as Mean+SEM, c Kaplan Maier survival curve, $\mathbf{d}-\mathbf{o}$ Each data point represents an individual mouse, horizontal lines represent the median of each treatment group $n=10$ for days 3 and $7, n=7$ for day 14 female NSG mice per group (results of one representative study out of two are presented). Statistical analysis performed using (a-b and d-o) Mann-Whitney test; c Log-rank (Mantel-Cox) test. $* P \leq 0.05, * * P \leq 0.01, * * * P \leq 0.001$, $* * * * P \leq$ $0.0001, P \leq 0.001$.

helper $\left(\mathrm{T}_{\mathrm{H}}, \mathrm{CD}^{+}\right)$and cytotoxic $\mathrm{T}$ cells $\left(\mathrm{T}_{\mathrm{C}}, \mathrm{CD} 8^{+}\right)$, memory and effector $T$ cells, and $\mathrm{T}_{\mathrm{H}} 1 / \mathrm{T}_{\mathrm{C}} 1$ and $\mathrm{T}_{\mathrm{H}} 17$ cells (Fig. 2c). Recent studies suggest that acute GvHD is mediated in part by mature donor $\mathrm{T}_{\mathrm{H}} 1$ and $\mathrm{T}_{\mathrm{H}} 17$ cells present in the allograft that recognize minor or major histocompatibility disparities between donor and host [34, 35]. In addition to fully differentiated $\mathrm{T}$-cell populations, $\mathrm{T}_{\mathrm{SCM}}$ includes a minor population of self-renewing cells which 

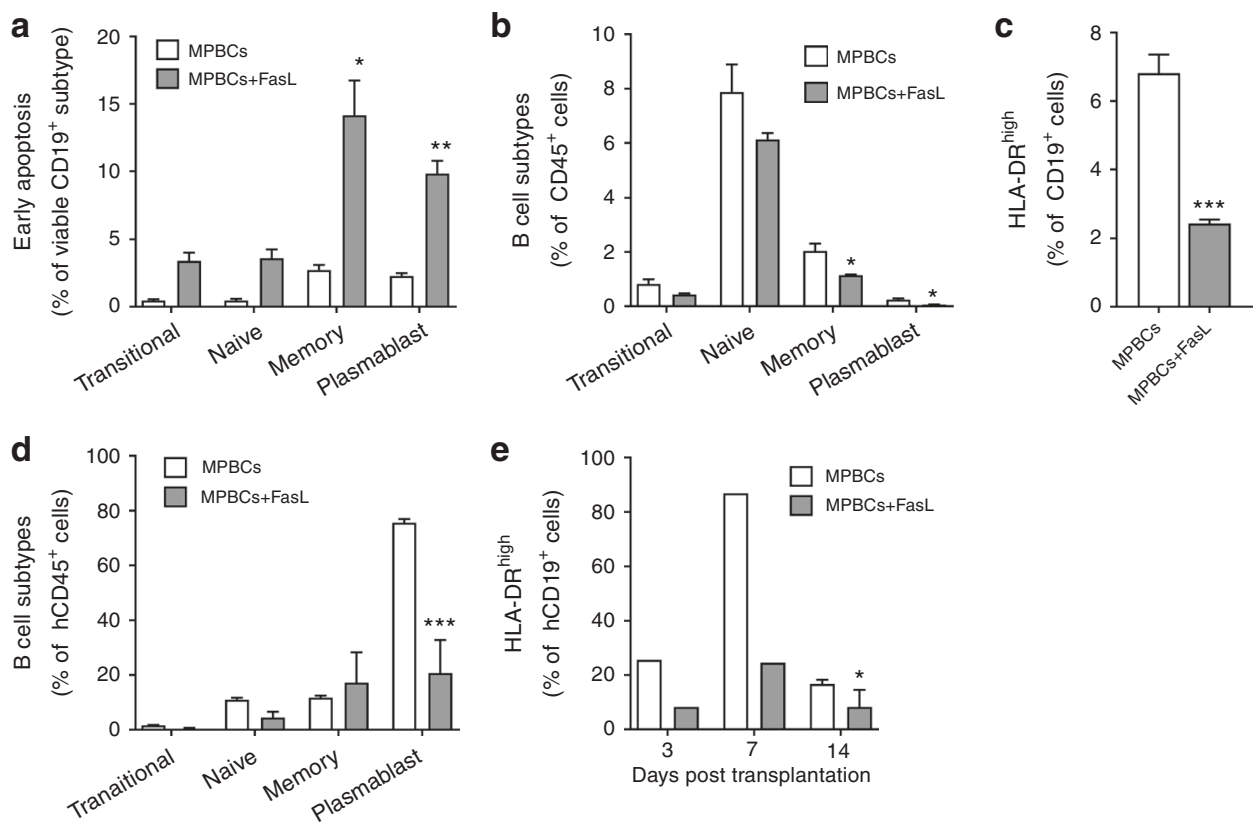

Fig. 5 FasL treatment changes the composition of the $B$ cell compartment. In vitro $(\mathbf{a}-\mathbf{c})$ and in vivo $(\mathbf{d}-\mathbf{e})$ studies demonstrate the effect of FasL treatment on B cells. a Early apoptosis $\left(\right.$ AnnexinV $^{+} / 7$ $\left.\mathrm{AAD}^{-}\right)$and $\mathbf{b}$ percentages of $\mathrm{B}$ cell subtypes [Transitional $\left(\mathrm{CD} 27^{-}\right.$ $\left.\mathrm{CD} 38^{+}\right)$, Naïve $\left(\mathrm{CD} 27^{-} \mathrm{CD} 38^{-}\right)$, Memory $\left(\mathrm{CD} 27^{+} \mathrm{CD} 38^{-}\right)$, and Plasmablast $\left(\mathrm{CD} 27^{+} \mathrm{CD} 38^{+}\right)$], $\mathbf{c}$ percentage of HLA-DR ${ }^{\text {high }}$ expressing B cells in control- and FasL-treated MPBCs. d Percentage of human B-lymphocytes

expands in the host early after transplantation [36-38], and the dynamics of $\mathrm{T}_{\mathrm{SCM}}$ expansion and contraction correlates with GvHD-free survival [39, 40]. These cells are at the cusp of the transition between naïve and effector state and may serve as a cellular reservoir for GvHD-inducing cells. It is not surprising, therefore, that partial depletion of these cells from the graft by FasL treatment would ameliorate GvHD. Tandem depletion of less differentiated $\mathrm{T}_{\mathrm{SCM}}$ cells and mature, IFN- $\gamma$ secreting $\mathrm{T}$ cells may shape the alloreactive post-transplant $\mathrm{T}$ cell milieu, reducing the risk of severe GvHD. Recent descriptions of the role of $\mathrm{T}$ cell collectivity and the influence of small $\mathrm{T}$ cell populations on antigen response suggest that even partial depletion of small but influential $\mathrm{T}$ cell subpopulations within the graft's lymphocyte compartment may have substantial effects on post-transplantation alloreactivity. Further elucidation of the rules of $\mathrm{T}$ cell social behavior will likely continue to inform the future development of novel GvHD therapeutics [41].

During stem cell engraftment, donor T cells interact with both host and donor APCs; host APCs present host major and minor histocompatibility antigens to donor $\mathrm{T}$ cells priming the acute GvHD reaction [6]. T-cell recognition of MHC molecules is species-restricted; human TCRs do not recognize mouse MHC. GvHD in xenogeneic transplant of human MPBCs into immunodeficient NSG mice ensues when HLA proteins on APCs contained in the graft process subtypes in spleens 14 days post transplantation of either control or FasLtreated-MPBCs into NSG mice and $\mathbf{e}$ the percentage of HLA-DR ${ }^{\text {high }}$ expressing human-B-lymphocytes 3, 7 and 14 days post transplantation. Data presented as Mean + SEM. Statistical analysis was performed using (a-c) Student's $t$ test and (d, e) Mann-Whitney test; $* P<0.05, * * P<0.01$, $* * * P<0.001, n=10$ for days 3 and $7, n=7$ for day 14 female NSG mice per group.

and present mouse antigens to $\mathrm{T}$ cells that are also contained within the graft [31,32]. Indeed, in our model, donorderived $\mathrm{T}$ and $\mathrm{B}$ cells co-accumulate in the spleen presaging the appearance of GvHD (Fig. 4d). Brief incubation of MPBCs with FasL resulted in increased apoptosis among transitional, naïve, memory and plasmablastoid B cells, leading to a reduction in their percentage within the treated graft (Fig. 5a, b), and, eventually, within the spleen of transplanted mice (Fig. 5d, e). Furthermore, FasL treatment selectively reduced the percentage of putative antigenpresenting HLA-DR ${ }^{\text {high }}$ expressing $B$ cells in vitro and in vivo (Fig. 5c, e). Induction of apoptosis and reduction in the number of myeloid APCs that express HLA-DR ${ }^{\text {high }}$ was found in vitro as well as in vivo in the spleen of mice transplanted with FasL-treated grafts (Supplementary Fig. 3). This FasL-induced decrease in antigen-presenting capacity corelated with lower GVHD scores and mortality.

We did not directly measure markers of inflammation in treated and control mice, but speculate that FasL-mediated changes in graft composition may reduce levels of inflammation and promote short-term HSC engraftment and hematopoietic recovery.

Host APCs play an important role in the balance between the induction of GvHD and the development of tolerance [42]. Phagocytosis of apoptotic cells converts immature dendritic cells (DCs) into tolerogenic DCs, abrogating 
a

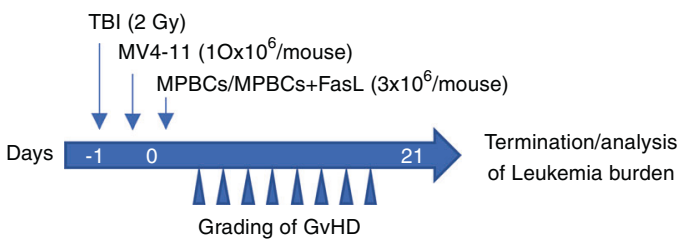

b
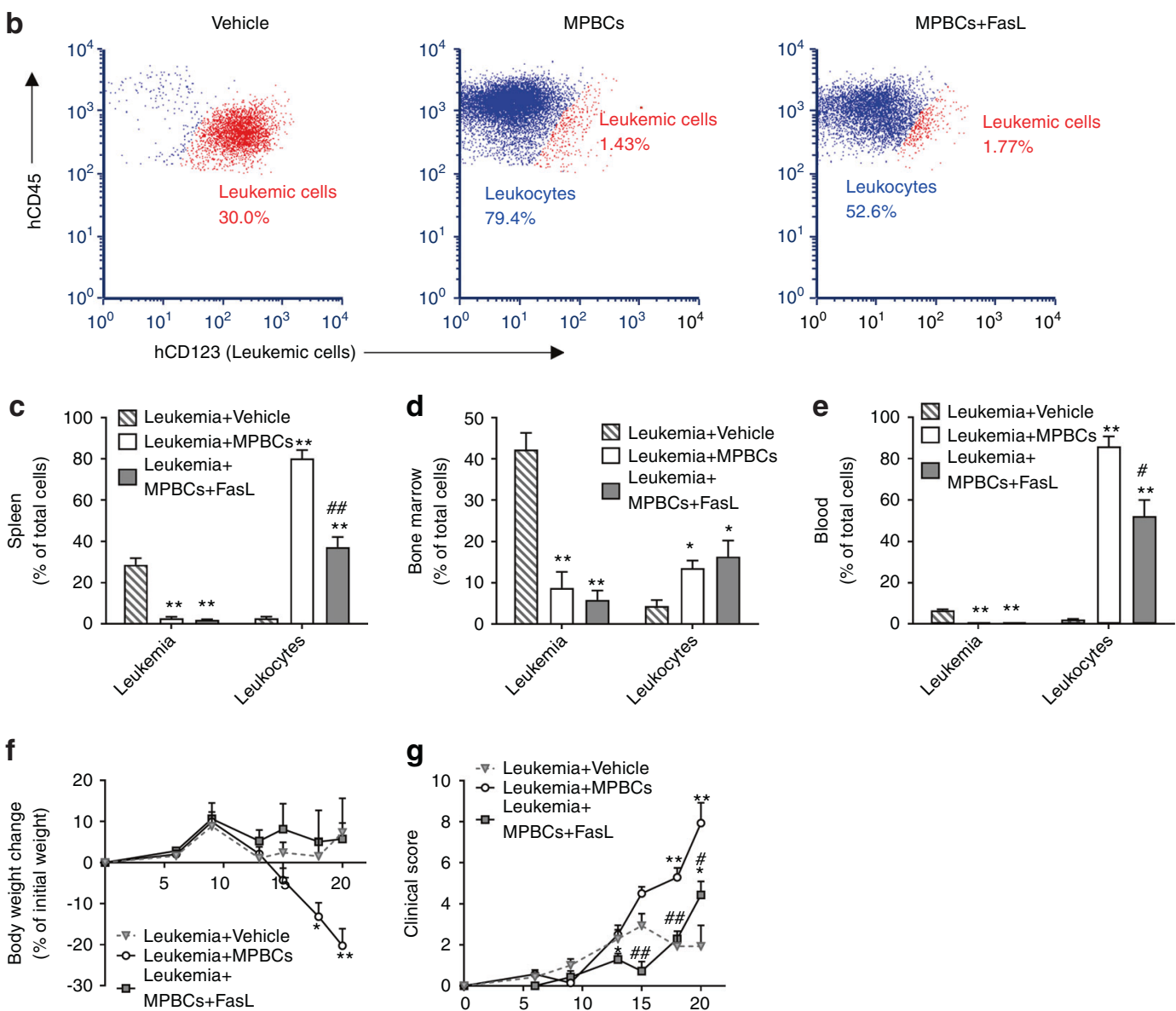

Fig. 6 FasL prevents GvHD but preserves GvL in vivo. a Graft vs. leukemia model: 1 day following sub-lethal $\gamma$-irradiation ( $2 \mathrm{~Gy}), 10 \times$ $10^{6}$ MV4-11 leukemic cells were administered by intravenous (IV) bolus injection followed $4-6 \mathrm{~h}$ later by infusion of either $3 \times$ $10^{6}$ MPBCs or FasL-treated-MPBCs. Animals were evaluated twice weekly for clinical signs of GvHD. Human hematopoietic cell engraftment and leukemic burden were assessed 3 weeks post transplantation in blood, BM and spleen by flow cytometry. b Representative flow cytometry dot plot analysis of splenocytes,

GvHD [43, 44]. Several different techniques can be used to increase the number of apoptotic cells within the graft. Apoptosis can be induced by incubation of the graft with a photoactivated dye (8-Methoxypsoralen) followed by exposure to ultraviolet light, a process which is exploited clinically in extracorporeal photopheresis (ECP) in GvHD patients unresponsive to conventional immunosuppressive drugs [45], and FasL-induced apoptosis of lymphocytes contained the grafts used in these studies may lead displaying leukemic cells (hCD $45^{+} \mathrm{hCD} 123^{+}$) and human leukocytes $\left(\mathrm{hCD} 45^{+} \mathrm{hCD} 123^{-}\right)$. Data are representative of one of two independent experiments. Percentage of human leukemic cells and human leukocytes in the (c) spleen, (d) BM and (e) blood. (f) Body weight change and (g) clinical GvHD scores of NSG leukemic mice injected with FasL-treated or control MPBC. Data are presented as Mean + SEM, $(n=7$ female NSG mice per group). $* P<0.05$, $* * P<0.01$ versus Vehicle treated group and ${ }^{\#} P<0.05,{ }^{\# \#} P<0.01$ versus MPBCs control group (Mann-Whitney test).

to immunomodulation of macrophages and DCs and reduced rates of GvHD [46, 47]. Support for this theory is provided by suppression of GvHD by FasL pretreatment of transplanted grafts in a model that uses syngeneic mice [24].

Ex vivo $\mathrm{T}$ cell depletion from donor grafts has been used to prevent GvHD for more than 40 years. Iterations of this technique include positive selection of $\mathrm{CD}_{3} 4^{+}$hematopoietic stem cell progenitors and immunomagnetic depletion of target $\mathrm{T}$ cell populations [7]. Other approaches have 
been developed to deplete GvHD causing cells in vivo using anti-T-cell antibodies, or the administration of posttransplant cyclophosphamide [48]. Despite the positive effects of GvHD reduction seen after the administration of these modalities, patients often pay a price for $\mathrm{T}$ cell depletion, manifest by delayed immune recovery and attenuation of GvL effects. Brief incubation ( $2 \mathrm{~h}$ ) of MPBCs with hexameric Fas ligand, offers a novel ex vivo technology to treat GvHD by selectively depleting specific subsets of $\mathrm{T}$ cells, together with the ability to attenuate donor and host allo-antigen presentation involved in GvHD. Engraftment in our murine model is robust following transplantation of treated graft, and the graft retains its immune reconstitution and anti-leukemic effects A phase I clinical trial using such graft in adults undergoing stem cell transplant for the treatment of hematological malignancies is currently underway (NCT02828878).

Acknowledgements The authors thank Alla Zozovsky and Anna Zemlyansky for their excellent technical support.

Author contributions HL-B, LS-P, GR, AS, MR, LG, AR, NM, MA and IM performed the experiments and collected the data used in this paper. RB-K, SY, HW, TK, YB, TZ and JS conceived and designed the experiments described in this paper and analyzed the data produced. Amnon Peled contributed data and analytic tools. The paper was written by HL-B, LS-P, AP and JS. All authors read, commented on and approved the manuscript.

\section{Compliance with ethical standards}

Conflict of interest HL-B, LS-P, GR, AS, MR, LG, AR, NM, RB-K are employees of Cellect Biotherapeutics, and SY is an employee and shareholder of the same concern. AP serves as paid consultant for Cellect Biotherapeutics. MA, IM, HW, TK, YB, TZ and JS declare no competing financial interests. This technology is covered by patents and pending patents.

Publisher's note Springer Nature remains neutral with regard to jurisdictional claims in published maps and institutional affiliations.

Open Access This article is licensed under a Creative Commons Attribution 4.0 International License, which permits use, sharing, adaptation, distribution and reproduction in any medium or format, as long as you give appropriate credit to the original author(s) and the source, provide a link to the Creative Commons license, and indicate if changes were made. The images or other third party material in this article are included in the article's Creative Commons license, unless indicated otherwise in a credit line to the material. If material is not included in the article's Creative Commons license and your intended use is not permitted by statutory regulation or exceeds the permitted use, you will need to obtain permission directly from the copyright holder. To view a copy of this license, visit http://creativecommons. org/licenses/by/4.0/.

\section{References}

1. Saraceni F, Shem-Tov N, Olivieri A, Nagler A. Mobilized peripheral blood grafts include more than hematopoietic stem cells: the immunological perspective. Bone Marrow Transpl. 2015;50:886-91.

2. Martin PJ, Hansen JA, Buckner CD, Sanders JE, Deeg HJ, Stewart P, et al. Effects of in vitro depletion of T cells in HLAidentical allogeneic marrow grafts. Blood. 1985;66:664-72.

3. Goldman JM, Gale RP, Horowitz MM, Biggs JC, Champlin RE, Gluckman E, et al. Bone marrow transplantation for chronic myelogenous leukemia in chronic phase. Increased risk for relapse associated with T-cell depletion. Ann Intern Med. 1988;108:806-14.

4. Maraninchi D, Gluckman E, Blaise D, Guyotat D, Rio B, Pico JL, et al. Impact of T-cell depletion on outcome of allogeneic bonemarrow transplantation for standard-risk leukaemias. Lancet. 1987;2:175-8.

5. Duffner UA, Maeda Y, Cooke KR, Reddy P, Ordemann R, Liu C, et al. Host dendritic cells alone are sufficient to initiate acute graftversus-host disease. J Immunol. 2004;172:7393-8.

6. Chakraverty R, Sykes M. The role of antigen-presenting cells in triggering graft-versus-host disease and graft-versus-leukemia. Blood. 2007;110:9-17.

7. Or-Geva N, Reisner Y. The evolution of T-cell depletion in haploidentical stem-cell transplantation. Br J Haematol. 2016;172:667-84.

8. Martelli MF, Di Ianni M, Ruggeri L, Pierini A, Falzetti F, Carotti A, et al. "Designed" grafts for HLA-haploidentical stem cell transplantation. Blood. 2014;123:967-73.

9. Anderson BE, McNiff J, Yan J, Doyle H, Mamula M, Shlomchik MJ, et al. Memory CD4+ T cells do not induce graft-versus-host disease. J Clin Invest. 2003;112:101-8.

10. Chen BJ, Cui X, Sempowski GD, Liu C, Chao NJ. Transfer of allogeneic CD62L- memory $\mathrm{T}$ cells without graft-versus-host disease. Blood. 2004;103:1534-41.

11. Zhang Y, Joe G, Zhu J, Carroll R, Levine B, Hexner E, et al. Dendritic cell-activated CD44hiCD8 $+\mathrm{T}$ cells are defective in mediating acute graft-versus-host disease but retain graft-versusleukemia activity. Blood. 2004;103:3970-8.

12. Chen BJ, Deoliveira D, Cui X, Le NT, Son J, Whitesides JF, et al. Inability of memory $\mathrm{T}$ cells to induce graft-versus-host disease is a result of an abortive alloresponse. Blood. 2007;109:3115-23.

13. Dutt S, Tseng D, Ermann J, George TI, Liu YP, Davis CR, et al. Naive and memory $\mathrm{T}$ cells induce different types of graft-versushost disease. J Immunol. 2007;179:6547-54.

14. Zheng H, Matte-Martone C, Li H, Anderson BE, Venketesan S, Sheng Tan $\mathrm{H}$, et al. Effector memory CD4+ T cells mediate graftversus-leukemia without inducing graft-versus-host disease. Blood. 2008;111:2476-84.

15. Zheng H, Matte-Martone C, Jain D, McNiff J, Shlomchik WD. Central memory CD8 $+\mathrm{T}$ cells induce graft-versus-host disease and mediate graft-versus-leukemia. J Immunol. 2009;182:5938-48.

16. Bleakley M, Heimfeld S, Loeb KR, Jones LA, Chaney C, Seropian $\mathrm{S}$, et al. Outcomes of acute leukemia patients transplanted with naive T cell-depleted stem cell grafts. J Clin Invest. 2015;125:2677-89.

17. Triplett BM, Muller B, Kang G, Li Y, Cross SJ, Moen J, et al. Selective T-cell depletion targeting CD45RA reduces viremia and enhances early $\mathrm{T}$-cell recovery compared with CD3-targeted Tcell depletion. Transpl Infect Dis. 2018;20. https://doi.org/10. 1111/tid.12823.

18. Green DR, Llambi F. Cell death signaling. Cold Spring Harb Perspect Biol. 2015;7:a006080.

19. Strasser A, Jost PJ, Nagata S. The many roles of FAS receptor signaling in the immune system. Immunity. 2009;30:180-92.

20. Pearl-Yafe M, Stein J, Yolcu ES, Farkas DL, Shirwan H, Yaniv I, et al. Fas transduces dual apoptotic and trophic signals in hematopoietic progenitors. Stem Cells. 2007;25:3194-203.

21. Kim H, Whartenby KA, Georgantas RW 3rd, Wingard J, Civin CI. Human CD34+ hematopoietic stem/progenitor cells express high levels of FLIP and are resistant to Fas-mediated apoptosis. Stem Cells. 2002;20:174-82. 
22. Georgantas RW 3rd, Bohana-Kashtan O, Civin CI. Ex vivo soluble fas ligand treatment of donor cells to selectively reduce murine acute graft versus host disease. Transplantation. 2006;82:471-8.

23. Bohana-Kashtan O, Morisot S, Hildreth R, Brayton C, Levitsky HI, Civin CI. Selective reduction of graft-versus-host diseasemediating human $\mathrm{T}$ cells by ex vivo treatment with soluble Fas ligand. J Immunol. 2009;183:696-705.

24. Askenasy N, Mizrahi K, Ash S, Askenasy EM, Yaniv I, Stein J. Depletion of naive lymphocytes with fas ligand ex vivo prevents graft-versus-host disease without impairing $\mathrm{T}$ cell support of engraftment or graft-versus-tumor activity. Biol Blood Marrow Transpl. 2013;19:185-95.

25. Whitby A, Whitby L, Fletcher M, Reilly JT, Sutherland DR, Keeney M, et al. ISHAGE protocol: are we doing it correctly? Cytom B Clin Cytom. 2012;82:9-17.

26. Barnett D, Janossy G, Lubenko A, Matutes E, Newland A, Reilly JT. Guideline for the flow cytometric enumeration of CD34+ haematopoietic stem cells. Prepared by the CD34+ haematopoietic stem cell working party. General Haematology Task Force of the British Committee for Standards in Haematology. Clin Lab Haematol. 1999;21:301-8.

27. Cooke KR, Kobzik L, Martin TR, Brewer J, Delmonte J Jr, Crawford JM, et al. An experimental model of idiopathic pneumonia syndrome after bone marrow transplantation: I. The roles of minor $\mathrm{H}$ antigens and endotoxin. Blood 1996;88:3230-9.

28. Majeti R, Park CY, Weissman IL. Identification of a hierarchy of multipotent hematopoietic progenitors in human cord blood. Cell Stem Cell. 2007;1:635-45.

29. Wilson A, Trumpp A. Bone-marrow haematopoietic-stem-cell niches. Nat Rev Immunol. 2006;6:93-106.

30. Sahin AO, Buitenhuis M. Molecular mechanisms underlying adhesion and migration of hematopoietic stem cells. Cell Adh Migr. 2012;6:39-48.

31. Lucas PJ, Shearer GM, Neudorf S, Gress RE. The human antimurine xenogeneic cytotoxic response. I. Dependence on responder antigen-presenting cells. J Immunol. 1990;144:4548-54.

32. Schroeder MA, DiPersio JF. Mouse models of graft-versus-host disease: advances and limitations. Dis Model Mech. 2011;4:318-33.

33. Negrin RS. Graft-versus-host disease versus graft-versus-leukemia. Hematol Am Soc Hematol Educ Program. 2015;2015:225-30.

34. Carlson MJ, West ML, Coghill JM, Panoskaltsis-Mortari A, Blazar BR, Serody JS. In vitro-differentiated TH17 cells mediate lethal acute graft-versus-host disease with severe cutaneous and pulmonary pathologic manifestations. Blood. 2009;113:1365-74.

35. Zhao XY, Xu LL, Lu SY, Huang XJ. IL-17-producing T cells contribute to acute graft-versus-host disease in patients undergoing unmanipulated blood and marrow transplantation. Eur J Immunol. 2011;41:514-26.
36. Zhang Y, Joe G, Hexner E, Zhu J, Emerson SG. Host-reactive CD8+ memory stem cells in graft-versus-host disease. Nat Med. 2005;11:1299-305.

37. Cieri N, Oliveira G, Greco R, Forcato M, Taccioli C, Cianciotti B, et al. Generation of human memory stem $\mathrm{T}$ cells after haploidentical T-replete hematopoietic stem cell transplantation. Blood 2015; 125:2865-74.

38. Roberto A, Castagna L, Zanon V, Bramanti S, Crocchiolo R, McLaren JE, et al. Role of naive-derived T memory stem cells in $\mathrm{T}$-cell reconstitution following allogeneic transplantation. Blood 2015;125:2855-64.

39. Gattinoni L, Lugli E, Ji Y, Pos Z, Paulos CM, Quigley MF, et al. A human memory $\mathrm{T}$ cell subset with stem cell-like properties. Nat Med. 2011;17:1290-7.

40. Gattinoni L, Speiser DE, Lichterfeld M, Bonini C. T memory stem cells in health and disease. Nat Med. 2017;23: $18-27$.

41. Polonsky M, Rimer J, Kern-Perets A, Zaretsky I, Miller S, Bornstein $\mathrm{C}$, et al. Induction of CD4 $\mathrm{T}$ cell memory by local cellular collectivity. Science. 2018;360:eaaj1853.

42. Tugues S, Amorim A, Spath S, Martin-Blondel G, Schreiner B, De Feo D, et al. Graft-versus-host disease, but not graft-versusleukemia immunity, is mediated by GM-CSF-licensed myeloid cells. Sci Transl Med. 2018;10:eaat8410.

43. Florek M, Sega EI, Leveson-Gower DB, Baker J, Muller AM, Schneidawind D, et al. Autologous apoptotic cells preceding transplantation enhance survival in lethal murine graft-versus-host models. Blood 2014;124:1832-42.

44. Dangi A, Yu S, Luo X. Apoptotic cell-based therapies for promoting transplantation tolerance. Curr Opin Organ Transpl. 2018; 23:552-8.

45. Perfetti P, Carlier P, Strada P, Gualandi F, Occhini D, Van Lint MT, et al. Extracorporeal photopheresis for the treatment of steroid refractory acute GVHD. Bone Marrow Transpl. 2008;42: 609-17.

46. Kleinclauss F, Perruche S, Masson E, de Carvalho Bittencourt M, Biichle S, Remy-Martin JP, et al. Intravenous apoptotic spleen cell infusion induces a TGF-beta-dependent regulatory T-cell expansion. Cell Death Differ. 2006;13:41-52.

47. Mevorach D, Zuckerman T, Reiner I, Shimoni A, Samuel S, Nagler A, et al. Single infusion of donor mononuclear early apoptotic cells as prophylaxis for graft-versus-host disease in myeloablative HLA-matched allogeneic bone marrow transplantation: a phase I/IIa clinical trial. Biol Blood Marrow Transpl. 2014;20:58-65.

48. Luznik L, O’Donnell PV, Fuchs EJ. Post-transplantation cyclophosphamide for tolerance induction in HLA-haploidentical bone marrow transplantation. Semin Oncol. 2012;39:683-93. 